\title{
PUSAT STUDI LEMBAGA PEMASYARAKATAN FAKULTAS HUKUM UKI
}

\author{
Oleh: Petrus Iwan Panjaitan \\ petrus.pandjaitan@yahoo.com \\ Universitas Kristen Indonesia, Jakarta, Indonesia
}

\begin{abstract}
Pusat Studi Lembaga Pemasyarakatan is an institution that conducts scienti c analysis of the correctional system; inmate behavior; of cer behavior; coaches behavior; the regulations that apply in Corrections Institutions; facilities available to the public's view of the Penitentiary; in addition there are also problems that occur in the Penitentiary; such as a criminal period that is too short; community prisoners' social relations; the problem of assimilation into and outside the institution and the problem of the prisoner's biological needs; can be analyzed or studied in more depth; to make effective analysis of the existence of Correctional Institutions requires an academic authority through the Higher Education Law Institution as a Higher Education Institution, the UKI Faculty of Law should properly have a Correctional Institution Study Center when entering the age of 40 years as well as maintaining the best predicate among the Law Pakuitas as a consideration of establishment Study Centers that until now there has not been a Faculty of Law that has such Study Centers; Penitentiary a strategic part of the criminal justice system; Penal Institutions need to be empowered in their role in society.
\end{abstract}

Keywords: Lembaga Pemasyarakatan; prison; study center; criminal justice system.

\section{PENDAHULUAN}

Diusaanya yang ke-40 tahun (1958-1998), Fakultas Hukum UKI sepatutnya mempertimbangkan berdirinya Pusat Studi Lembaga Pemasyarakatan (PSLP). Sebagai Fakultas Hukum yang terbaik menurut penilaian Badan Akreditasi Nasional (BAN), Fakultas Hukum UKI harus terus memacu prestasi akademik para mahasiswa maupun dosen dengan mengedepankan Pusat Studi-Pusat Studi yang dianggap mampu untuk dikembangkan.

Pertimbangan, mendirikan Pusat Studi Lembaga Pemasyarakatan di Fakultas Hukum UKI :

1. Sampai sekaratig ini belum ada Fakultas Hukum di Indonesia yang memiliki Pusat Studi Lembaga Pemasyarakatan;

2. Lembaga Pemasyarakatan sebagai bagian dari Sistetn Peradilan Pidana, merupakan tempat strategis dalam membina pelanggar hukum menjadi taat hukum;

3. Lembaga Pemasyarakatan menjadi pusat perhatian bagi kalangan akademisi mengingat sering terjadi perkelahian, pelarian yang dilakukan oleh narapidana serta penyimpangan yang dilakukan oleh petugas;

4. Sebagai Lembaga Pembinaan, Lembaga Pemasyarakatan perlu diberdayakan peranannya dalana masyarakat, khususnya pembinaan sumber daya marmsia.

Secara sederhana dapat kita pahami bahwa Pusat Studi Lembaga Pemasyarakatan Lembaga yang melakukan analisis ilmiah mengenai pemasyarakatan; perilaku narapidana, perilaku petugas, perilaku, pembina; peraturan-peraturan yang berlaku di Lembaga Pemasyatakatan, saxana-sarana yang tersedla sampai kepada pandangan masyarakat terhadap Lembaga Pemasyarakatan itu sendiri.

Tulisan ini bertujuan memberikan sumbangan pemikiran mengenai perbaikan perlakuan narapidana serta memperbaiki citra Lembaga Pemasyarakatan di masyarakat dan menjadikan Pakultas Hukuni UKI berperan di tengah-tengah Perguruan Tinggi Hukum serta masyarakat.

\section{PEMBAHASAN \\ Lembaga Pemasyarakatan}

Lembaga Pemasyarakatan (LP) yang dahulu 
disebut Penjara, mulai mendapat perhatian sejak Sahardjo sebagai Menteri Kehakimanmengetengahkan perlunya memberdayakan narapidana walaupun mereka itu sebagai pelanggar hokum. Pembaruan (reformasi) terhadap pembinaan narapidana diawali pidato Sahardjo di Universitas Indonesia (UI) pada saat menerima gelar Doktor Honoris Causa pada tanggal 5 Juli 1963 yang mengatakan : narapidana adalah orang tersesat yang mempunyai waktu dan kesempatan untuk bertobat. Keadaan ini berlanjut dengan diadakannya Konferensi Dinas Kepala-Kepala Penjara dari seluruh Indonesia pada tanggal 27 April 1964 di Lembang Bandung serta ditetapkannya 10 (sepuluh) prinsip pokok pemasyarakatan dengan sistem pemasyarakatan metoda serta pemasyarakatan suatu proses. Perbaikan pun terjadi pada Lembaga Pemasyarakatan. Seperti mengganti bangunanbangunan yang sudah tua, serta bentuk-bentuk perlakuan lainnya. Digantinya Gestichten Reglement 1917 Stb. 708 (reglemen Penjara 1917 No, 708) dengan Undang Undang Pemasyarakatan No. 12 Tahun 1995 membuktikan adanya keseriusan untuk memperbaiki citra Lembaga Pemasyaraka$\tan$.

Lembaga Pemasyarakatan sebagai bagian dari sistem Peradilan dalam kenyataannya menyimpan berbagai misteri, sebagaimana dikatakan oleh Thomas Sunaryo.

Penjara yang tampaknya tenteram dari luar, sebenarnya menyelubungi tragedi-tragedi kemanusiaan di dalamnya dalam dimensi-dimensi yang mencekam dari apa yang tampak bagi dunia luar sebagai insiden-insiden yang meresahkan seperti pelarian dan lain-lain. Baik pelarian fisik maupun pelarian mental (Psycological Withdrawal) dan berupa wujud tingkah laku dimana para narapidana menghayalkan kebidupan di alam bebas di luar penjara.

Pendapat di atas mengajak kita untuk memahami apa yang terjadi di Lembaga Pemasyarakatan, serta berusaha mencari jalan pemecahannya.

Kenyataan yang terjadi, bahwa perkelahian, pelarian serta berbagai penyimpangan yang sering terjadi di Lembaga Pemasyarakatan, bukan merupakan hal rahasia, begitu juga mengenai penyimpangan seksual narapidana, pemerasan sesama narapidana bahkan perlakuan kasar petugas terhadap narapidana sudah merupakan hal yang biasa. Oleh sebab itu pembinaan narapidana di Lembaga Pemasyarakatan haruslah diarahkan kepada kegiatan-kegiatan yang bersifat memberi bekal pengetahuan. Hal ini sesuai dengan pembinaan narapidana di dalam Lembaga Pemasyaraka$\tan$;

Reintegrasi, yakni mengembalikan kesatuan hubungan hidup dan kehidupan antara narapidana dan masyarakat luas melalui pembinaan narapidana yang kolaboratif, yaitu kerjasama antara petugas terpidana dan masyarakat untuk mengurangi keterasingan (isolasi) dengan kebidupan masyarakat luas baik dalam arti fisik maupun nilai-nilai masyarakat. ${ }^{2}$

\section{Masalah-Masalah Dalam Pembinaaan Narapi- dana}

Berbagai masalah pembinaan narapidana yang menjadi bahan kajian pada Pusat Studi Lembaga Pemasyatakatan, dapat diinventarisir pada hal-hal berikut:

\section{Masalah Pidana yang Terlalu Singkat}

Hambatan yang menonjol dalam pembinaan narapidana adalah masa pidana yang terlalu singkat, hal ini menyulitkan petugas melakukan proses pembinaan dengan sistem pemasyarakatan. Secara ideal setiap narapidana harus melewati tahap-tahap, yaitu : Taimp 1 : Tahap Maximum Security, Tahap II : Tahap Medium Security, Tahap HI : Tahap Minimum Security, Tahap IV : Tahap Integrasi Kenyataan yang terjadi di LP menunjukkan bahwa sebelum narapidana itu menjalani semua tahapan, narapidana itu telah bebas. Jadi dapat disimpulkan bahwa pembinaan narapidana tidak sempurna dan kerapkali menimbulkan residivis dan gejolak di masyarakat.

\section{Narapidana, Petugas daa Masyarakat}

Dalam sistem pemasyarakatan ada tiga unsur penting yang terlibat, yaitu narapidana, petugas dan masyarakat. Sebagai unsur pertama, narapidana harus memahami posisinya, khususnya saat menjalani hukuman. Artinya 
narapidana harus sadar bahwa dia adalah orang bersalah. Namun sering terjadi narapidana mengeluh dikarenakan tidak pernah dikunjungi keluarganya, hal ini mengakibatkan narapidana kuatir akan masa depannya. Bagi pihak lembaga kalau ini tidak diatasi, maka lembaga gagal melakukan pembinaan untuk selanjutnya. Hambatan lain dirasakan narapidana adalah pakaiaan seragam birubiru, secara psikologis pakaian seragam melambangkan mereka adalah orang-orang jahat, patut dihukum dan diawasi terus menerus. Disamping tekanan psikologis, akibat pakaian dan proses pembinaan sering terjadi bahwa narapidana tidak mampu menyesuaikan diri dengan segaian sarana yang tersedia, seperti makanan, tempat tidur terbatas. Dalam hal ini, narapidaaa harus dan menyadari apa itu Lembaga Pemasyarakatan secara historis, serta fungsi dan kemampuan pemerintah.

Sebagai unsur kedua, petugas faktor penting dalam pembinaan narapidana, petugas menjadi sorotan masyarakat, maupun dari narapidana, petugas lemah dari segi kepribadin maupun kemampuan, tidak dihargai oleh narapidana. Sering narapidana mengelabui petugas. Disamping itu petugas Lembaga Pemasyarakatan tidak pemah menjelaskan hak dan kewajiban setiap narapidana. Hal ini terjadi, karena tidak mengertinya petugas apa sebenarnya pemasyarakatan, minimnya pengetahuan dan rendahnya pendidikan. Merupakan suatu keayataan, kalau dikatakan bahwa petugas pembina di Lembaga Pemasyarakatan yang lulusan AKIP (Akadeini Ilmu Pemasyarakatan) tidaksebanding dengan narapidana. Dalam hal ini tingkat pendidikan dan pengetahuan setiap petugas sangat mempengaruhi proses pembinaan.

Sebagai unsur ketiga, masyarakat memiliki peranan strategis. Keterkaitan narapidana dan petugas petugas serta masyarakat sangat jelas terlihat setelah narapidana itu menjalani hukuman, khususnya hambatan dari keluarga. Keluarga bekum bisa percaya bahwa pembinaan yang dilakukan belum membantu memperbaiki narapidana. Ketidakpercayaan keluarga kepada Lembaga Pemasyarakatan berdasarkan yang melihat bekas narapidana melakukan kejahatan kembali. Kegagalan mentaati hukum di masyarakat menandakan ketidakpercayaan terhadap pembinaan. Sehubungan dengan hal ini, Lembaga Pemasyarakatan berkesimpulan bahwa. kegagalan pembinaan narapidana disebabkan anggota keluarga saat melakukan kunjungan sering memberikan informasi yang meresahkan narapidana, seperti keluarga yang kehabisan uang, anak-anak yang dikucilkan.

Disamping itu, masyarakat sering tidak memahami peranan dan fungsinya. Harus disadari bahwa narapidana itu merupakan produk dari masyarakat. Apa yang dihasilkan oleh masyarakat akan terlihat dalam lembaga. Artinya perangai narapidana sewaktu berada di masyarakat sangat menonjol di dalam lembaga.

Sikap masyarakat yang menolak bekas narapidana, baik tinggal di lingkungannya atau untuk bekerja, merupakan masalah klasik di dalam pembinaan narapidana seusai menjalani pidaana.

\section{Masalah Asimilasi ke Dalam dan ke Luar Lembaga}

Asimilasi ke dalam Lembaga Pemasyarakatan, khususnya kunjungan keluarga, merupakan unsur periting untuk mengobati rasa rindu. Dampak dari kunjungan keluarga akan memberi semangat si terpidana untuk menjalani hukuman. Namun timbul masalah dalam asimilasi, yaitu istri mengeluh akan kebutuhan biologis, keadaan ini menyebabkan tidak tenteramnya narapidana di dalam lembaga. Dampak dari ini semua, narapidana menaruh curiga pada istrinya begitu juga sebaliknya, akibatnya narapidana selalu berusaha melarikan diri. Oleh karena itu harus disadari, bahwa kekacauankekacauan yang terjadi di dalam lembaga ini tidak selamanya bersumber dari dalam saja, tapi juga dari luar.

Disamping asimilasi ke dalam, asimilasi ke luar tidak kalah pentingnya, berintegrasi narapidana dalam masyarakat salah satu 
terapi yang efektif. Manfaatnya narapidana dapat belajar menyesuaikan diri dengan lingkungannya. Disamping itu narapidana dapat membandingkan pahitnya di Penjaradengan sewaktu masih berada di masyarakat.

Masalah di dalam asimilasi ke luar adalah kesempatan cuti itu dimanfaatkan oleh narapidana kembali ke lingkungan semula. Begitu juga permohonan cuti sangat sulit diperoleh. Dalam momen-momen tertentu saja, cuti ini diberikan seperti menghadiri keluarga yang kemalangan, menjadi wali dalam perwakilan.

\section{Masalah Kebutuhan Biologis Narapi- dana}

Kebutuhan narapidana yangakhir-akhir ini banyak diperdebatkan adalah kebutuhan biologis, narapidana membutuhkan kebutuhan biologis. Sehubungan dengan hal ini perlu diperhatikan, yaitu narapidana menjadi malas atau rajin mengikuti kegiatan kalau kebutuhan seksualnya terpenuhi. Hal ini sangat penting untuk mencegah penyimpangan seksual sesama narapidana, yaitu terjadinya hubungan seksual sesama jenis. Mengatasi hal ini, pihak pemerintah membuat peraturan, yang berlaku di daerah tertentu saja yang disebut dengan cuti mengunjungi keluarga. Nanun ada usul yang menyatakan agar dibuat tempat khusus di dalam lembaga untuk memenuhi kebutuhan seksual dengan istri yang sah.

Bisamping hambatan-hambatan di atas, perlu juga melihat hubungan narapidana dengan petugas. Mengapa dikatakan demikian karena, satu fakor pendukung keberhasilan pembinaan narapidana tidak terlepas dari hubungan sosial mereka berintegrasi pada saat pembinaan, seperti apa yang dikemukakan oleh A. Alex Nefi :

Hubungan petugas terpidana di lembaga memperlihatkan adanya jarak sosial (social distance). Para terpidana terasing dari para petugas. Terpidana melihat petugas sebagai orang yang tidak dekat dengan mereka. Para terpidana cenderung hidup dalam dunianya sendiri, dan tidak menghiraukan para petu- gas karena hubungan petugas tidakbanyak artinya bagi kelangsungan hidup mereka di dalam LP. Para terpidana beranggapan lebih baik saling membina antara sesama hukuman bertolak dari dan perasaan yang sama, dengan demikan mereka akan dapat saling membaca kemauan dan keinginan masingmasing. Kadang-kadang terpidana melihat petugas penuh dengan sikap kebencian, tetapi tidak diketahui petugas secara langsang. Kalau mereka positif di sini tampak sikap pura-pura terus berkembang menjadi sebagian dari pola kehidupan di dalam LP.

Tidak adanya hubungan yang terbina antara petagas dari narapidana memberi kesan penjara sangat menonjol atau pengaruh kolonial san- gat terpatri di hati sanubari petagas. Dalam hal ini tidak terlalu jelas apa penyebab disharmoni antara dengan narapidana. Banyak pendapat dan analisis yang mencoba memberikan gambaran dan jawaban, yang menyatakan bahwa kesan bengis petugas merupakan suatu keharusan. Namun ada pendapat yang perlu disimak, seperti yang dikemukakan oleh, Purniati :

Dari berbagai wawancara yang tim peneliti lakukan para petugas LP yang menjadi responden, tampak adanya bahwa para petugas takut kehilangan kewibawaan terhadap narapidana sehubungan dengan diterapkannya sistem pemasyarakatan yang menonjolkan aspek hubungan yang mnusiawi. Aspek manusiawi tampaknya oleh para petugas LP diidentikkan dengan perlakuan lemah lembut tanpa sanksi. Dari kekkhawatirab tersebut, maka jelas pula terlihat pada pendapat-pendapat mereka bahwa sikap tegas, menjaga jarak serta bentuk-bentuk pemberian hukuman perlu ditonjokan dalam pola interaksi dengan narapidana

Pendekatan security, ternyata cara paling efektif di dalam sejarah penghukuman di Indonesia. Harus diakui secara jujur bahwa Lembaga Pemasyarakatan beserta petugasnya adalah suatu lembaga yang tidak terpikirkan mengapa dia sampai ada. Tetapi di satu pihak sulit membayangkan kalau lembaga ini tidak ada. Oleh karena itu sering 
petinggi hukum dan pakar-pakar pemasyarakatan dan hukum pidana kehilangan akal untuk mensiasati jalan keluar, bagaimana sebaiknya mengurusi yang namanya Lembaga Pemasyarakatan.

Berbagai pendekatan analisls sering dilakukan untuk memahami mengapa terjadi kekacauan di dalam LP dan bagaimana mengatasinya. Tujuannya semata-mata ingin mernperbaiki citra LP itu sendiri. Kenyataan menunjukkan bahwa masalah dalam sistem pembinaan narapidana bukan terletak pada sarana semata, tetapi menyangkut berbagai aspek.

Untuk memahami hal itu perlu mengungkapkan pemikiran J.E, Sahetapy :

Dalam pada itu perlu di sadari pula, bahwa tempat narapidana itu dinamakan LP atau penjara, sebetulnya tidak begita relevan. Yang mendasar bukanlah penggantian nama, melainkan struktur, proses dan mekanisme serta nilai-nilai sosial, aspek budaya di dalam maupun di luar LP yang paling menentukan. Hal ini nyata dalam penelitian Staiiton Wheeler (1969) di Penjara Botsfengslet di Oslo Norwegia, jika dibandingkan dengan kehidupan penjara di Amerika. Stanton Wheeler meiiulis bahwa penjara Botsfengslet "is just like an Sunday school, Bilamana anda membiarkan penjara Botsfengslet terbuka, para napi tidak akan melarikan diri, melainkan akan mendatangi para pengawal, petugas penjara dan bertanya, ada apa yang sedang terjadi.

Bagaimana kalau hal ini terjadi di Amerika ? Jelas, semua napi akan berbondongbodong dan berdesakan melarikan diri. Lalu bagaimana bila pintu LP di Indonesia dibiarkan terbuka ? Dari sudut Stanton Wheeler tersebut, ternyata "nilai-nilai sosial aspek budaya dan faktor struktural suatu masyarakat, yang saya akronirnkan dengan SOBURAL, sangatlah berperan dan menentukan. Jadi suatu pendekatan SOBURAL perlu dikaji dalam permasalahan LP di Indonesia.

Selanjutnya dikatakan J.E, Sahetapy:

Perhatikan bagaimana kita diajarkan di Sekolah Dasar, bahwa setali pembeli kemenyan sekupang pembeli ketaya, sekali lancang ke ujian, seumur hidup orang tak percaya. Ditambah dengan tidak mung-kin diberikan. Surat Kelakuan Baik oleh pihak Kepolisian, maka lengkaplah, stigmatisasi sang napi yang katanya dibina di dalam institusi dengan nama mentereng LP. Beberapa catatan akhir perlu merupakan catatan Pro Memori:

1. Sebelum diambil langkah-langkah konkrit untuk suatu kebijaksanaan pembinaan peru diteliti secara objektif tentang keadaan prisonisasi dan sub kultur napi dalam Lembaga Petnasyarakatan;

2. Perlu diwaspadai terhadap laporan ABS;

3. Ketrampilan dan keahlian para pembina LP harus dilengkapi dengan modal kejujuran dan dedikasi;

4. Selama budaya di luar LP tidak mendukung apa yang menjadi kebijakan dalam LP (intra mural), sia-sialah. Setnuanya. Dengan perkataan lain suatu SOBURAL yang sehat di luar LP (ekstra mural) jelas akan mempunyai dampak besar;

5. Sudah waktunya untuk menyusun suata Undang Undang LP, dan untuk itu, setiap ungkapan euphsmistis dan yang berbunga-bunga sudah ditiadakan, jadi susunlah secara luas dan objektif;

6. Selain probation perlu dipikirkan Halfway House seperti di Amerika;

7. Yang terutama bukan mengubah menjadi saleh/alim, melainkan bagaimana mempersiapkan napi untuk kembali ke dalam masyarakat.

\section{Pengorganisasian Pusat Studi Serta Mekan- isme Kerja}

Untuk mengefektifkan Pusat Studi Lembaga Pesaasyarakatan Fakultas Hukum UKI, dibutuhkan sarana : 1), Sumber daya manusia yang mempunyai minat dan kemampuan menjadi pengelola. 2). Sarana fisik berupa ruangan, peralatan komputer dan beberapa literatur, majalah-majalah, jurnal-jurnal serta mengoleksi beberapa hasil penelitian, hasil seminar yang menyangkut narapi- 
dana serta Lembaga Pemasyarakatan, Disamping itu, Pusat Stadi ini dijadikan sebagai bagian dari Departemen Hukum Pidana atau langsung di bawah Dekan.

Sebagai suatu Pusat Studi, diperlukan Me- kanisme kerja dengan menempatkan tenaga ahli di bidangnya, kuaitfikasi akademik seperti doktor maupun Magister. Adapun Struktur Organisasi Pusat Studi Lembaga Pemasyarakatan adalah sebagai berikut:

Ketua Pusat Studi; Sekretariat; Koordinator Peng- kajian Narapidana; Koordinator Sarana-sarana LP; Koordinator Pengkajian Hubungan Narapi- dana dengan Masyarakat.

\section{KESIMPULAN DAN SARAN}

Pusat Studi Lembaga Pemasyarakatan FH UKI, mempunyai sasaran kerja dengan kegiatan pengkajian- pengkajian atau studi pemasyarakatan narapidana. Dalam hal ini melakukan kerjasama dengan berbagai perguruan tinggi serta Kementerian Hukum dan Ham RI. Hasil-hasil Pusat Pengkajian LP dapat disebarlu- askan ke berbagai kalangan, seperti melalui jurnal, majalahmajalah sertaberbagai perpustakaan maupun untuk kepentingan penelitian instansi-instansi tertentu. Sebagai suatu gagasan ilmiah, usaha mendirikan Pusat Studi Lembaga Pemasyarakatan di Fakultas Hukum merupakan sumbangan pemikiran untuk pembangunan dan perbaikan kehidupan narapidana dimasa yang akan dating.

\section{Daftar Pustaka}

A. Alex Nefi, Paktor-Paktor Yang Menghambat Reintegrasi Sosiai Bekas Narapidana Ke Dalam Masyarakat, Kajian khusus terhadap narapidana residivis di LP Cipinang Jakarta, Thesis Magister Fakultas Pasca Saijana UI Bidang Ilmu Sosiai dan. Politik, 1987.

J.E. Sahetapy, Pengaruh Pembinaan Di Dalam LP Pada Napi Untuk Bermasyarakat, Makalah pada Seminar Pembinaan Narapidana MABES POLRI PTIK, Jakarta 12-15 Jarmari 1992.

Pumiati, Penerimaan Bekas Narapidana
Dalam Masyarakat, Makalah pada pertemuan ilmiah tentang Pola Pemidanaan, Penerimaan Bekas Narapidana, dan Saatunan Terhadap Korban Tiiidak Pidana, BPHN, Dep.Keh Jakarta, 19- 20 Pebuari 1992,

Thomas Sunaryo, Pungsi Dan Peranan Lembaga Pemasyarakatan Dalam Pembinaan Dan Bimbingan Terpidana (Beberapa Kendala Struktural), Makalah pada Seminar Nasional Bulan Kajian. Keilmuan SM-FH UI,'1991.

Majalah Bahana, Nomor 1 TahunV, Januari- Pebuari, 1983 
